\title{
Seasonality of habitat use, mortality and reproduction of the Vulnerable Antillean manatee Trichechus manatus manatus in the Orinoco River, Colombia: implications for conservation
}

\author{
Delma Nataly Castelblanco-Martínez, Ana Lucía Bermúdez-Romero \\ Is a bel Victoria Gómez-Camelo, Fernando Cesar Weber Rosas \\ FERNANDO TRUJILLO and ENRIQUE ZERDA-ORDoñEZ
}

\begin{abstract}
The Vulnerable Antillean manatee Trichechus manatus manatus (Mammalia, Sirenia) is threatened by hunting, entanglement in fishing nets and habitat degradation but most knowledge of the species comes from coastal and estuarine populations. We therefore studied an Antillean manatee population located $>1,100 \mathrm{~km}$ from the Caribbean coast, in the Orinoco River of Colombia, during 2001-2005. To verify the occurrence of the manatee and to investigate its habitat use throughout the annual hydrological cycle, we carried out surveys for manatees and manatee feeding signs over c. $40 \mathrm{~km}$ of the Orinoco River, between El Burro and Bachaco. We made 870 sightings in 1,003 hours of observation, and found 69 feeding areas in 776 hours of surveys. From 82 interviews in a total of 28 locations in Venezuela and Colombia we compiled 90 reports of manatees injured or killed in the Orinoco during 1980-2004. Both habitat use by the manatee and anthropogenic impacts on the species vary with the annual hydrological cycle. Reproduction appears to occur during the low water period in restricted areas that retain deep water. Improved knowledge of the dynamics of manatee migration and regulation of human activities, especially those related to use of nets and boat traffic, are required for conservation of the Antillean manatee in this freshwater habitat.
\end{abstract}

Keywords Colombia, habitat use, manatee, mortality, Orinoco River, Trichechus manatus manatus.

Delma Nataly Castelblanco-Martínez (Corresponding author) Proyecto Manati, El Colegio de la Frontera Sur, Av. Centenario km 5.5, CP 77900, Chetumal, Quintana Roo, México. E-mail castelblanco.nataly@gmail. com

Ana Lucía Bermúdez-Romero, Isabel Victoria Gómez-Camelo and Fernando Trujillo Fundación Omacha, Barrio El Polo, Colombia.

Fernando Cesar Weber Rosas Laboratório de Mamíferos Aquáticos/ INPA, Petrópolis, Manaus, Brazil.

EnRique Zerda-Ordoñez Universidad Nacional de Colombia, Sede Bogotá, Bogotá, Colombia.

Received 22 May 2007. Revision requested 26 July 2007.

Accepted 23 December 2007.

\section{Introduction}

The three species of manatees (Trichechus spp.) are 1 aquatic mammals of the Order Sirenia. There are conservation concerns for all three species because of collisions with boats, entanglement in fishing nets, hunting and habitat degradation, and all are categorized as Vulnerable on the IUCN Red List (IUCN, 2008).

Similar to the Florida manatee Trichechus manatus latirostris, the Antillean manatee Trichechus manatus manatus lives in salty, brackish and freshwater systems, sometimes alternating between the three environments (Lefebvre et al., 2001). Although it is known that some Antillean manatee populations live exclusively in the freshwater of the Orinoco River (O'Shea et al., 1988; Correa-Viana et al., 1990), most studies of the biology and ecology of the species have examined populations that live in coastal waters and estuaries (O'Shea \& Ackerman, 1995; Flamm et al., 2001). We therefore studied an Antillean manatee population located $>1,100 \mathrm{~km}$ from the Caribbean coast, in the Orinoco River of Colombia, from February 2001 to April 2005. The study involved interviewing local inhabitants and making direct observations and records of manatee feeding signs. In particular we aimed to identify areas used by the manatee in different seasons, describe any local migrations, and develop a simple model of habitat use in relation to mortality. Our overall aim was to provide information for the elaboration of management strategies for the species.

\section{Study area}

The study was carried out in the Orinoquía region, department of Vichada, Colombia, on the border with Venezuela, in the Reserva de Biósfera El Tuparro. The Orinoco is a clear-water, alkaline, tropical floodplain river system, with low levels of nutrients (Colonello, 1990). Temperature is high throughout the year (mean $28.1^{\circ} \mathrm{C}$, range $18.0-42.8^{\circ} \mathrm{C}$ ). There is a dry season from December to March, and the rainy period starts in April (Vasquez \& Wilbert, 1992). Because of this variation in annual precipitation there is a marked change in the level of the Orinoco River and its tributaries (Vasquez \& Wilbert, 
1992), resulting in a unimodal seasonal inundation that usually lasts for 4 months (Hamilton \& Lewis, 1990). The low water period is usually from January to April, with the lowest water level in March. The water rises in May-June, and the high water period is in July-October, with a peak in August. The amplitude between the low and high water periods is c. $13 \mathrm{~m}$ (Vasquez \& Wilbert, 1992). The river level falls in November-December. The flooded areas of the Orinoco are similar to other hydrographic systems, such as the Amazon, in amplitude, duration and ecological characteristics (Junk et al., 1989; Hamilton \& Lewis, 1990). Changes in the Orinoco River level in 2001-2004 are illustrated in Fig. 1. The study covered c. $40 \mathrm{~km}$ of the Orinoco River, (Fig. 2) from El Burro $\left(6^{\circ} 12^{\prime} \mathrm{N}, 67^{\circ} 26^{\prime} \mathrm{W}\right)$ to Bachaco $\left(5^{\circ} 55^{\prime} \mathrm{N}, 67^{\circ} 31^{\prime} \mathrm{W}\right)$.

\section{Methods}

Observations for manatees were carried out in 2001 (low water), 2002 (low and rising water), 2003 (low, rising and high water), 2004 (high and falling water) and 2005 (low water). Eight observation areas were chosen based on information about manatee presence provided by local inhabitants (Punta Lajas, Puerto Sucre, San José, Ventanas, Isla Santa Helena, La Angela, Isla Charal and Tronconal). Water depth was measured at three points in each area. Forest canopy and extreme seasonal water level changes make aerial surveys ineffective, and therefore observations were made during 6.30-17.00 for a minimum of 2 hours on each occasion. In areas such as the Orinoco River a combination of boat and land-based surveys are the only means of monitoring manatees. Four sighting methods were used: from high points on the river margins with a wide view of the area, from a small boat drifting with its engine off (average speed $4.0 \mathrm{~km} \mathrm{~h}^{-1}$ ), from an anchored boat, and from the river margins whilst walking. The total number of hours of observation at each site in each year are given in Table 1. Observations were suspended if either weather or waves would have interfered with data accuracy. Sightings were made when the manatees came up to breathe, when they expose their snout, back and sometimes their tail in a conspicuous way. Number of sightings per hour and maximum number of simultaneous sightings (manatees usually breathe simultaneously when in a group, and the maximum number of simultaneous sightings is the maximum number of manatees counted at the surface at one time) were used as relative indices of occurrence. Observations were also made of typical manatee feeding signs on leaves and stalks, which are easily distinguishable by experienced observers because there is no other aquatic herbivore that makes the same marks.

In 2001 (rising water period), 2002 (rising water period), 2003 (rising and high water periods) and 2004 (high and decreasing water periods) we searched for manatee feeding areas and made weekly observations for characteristic feeding signs, using transects, from a small boat with an engine travelling at an average speed of $8 \mathrm{~km} \mathrm{~h}^{-1}$. We made eight, eight, 16 and 17 transects at each of the eight sites in 2001, 2002, 2003 and 2004, respectively, except at the Punta Lajas site in 2004 where we made nine transects.

During 2001-2005 we carried out a total of 82 interviews in the cities of Puerto Carreño (Colombia) and Puerto Ayacucho (Venezuela) and in 28 fishing communities along the Orinoco and Meta River margins. Interviewees were men, without age restriction, who had some kind of contact with the species. For every recorded occurrence of a manatee killed, wounded, caught in a net or stranded, size class was determined according to weight and/or length estimated by the interviewee, as a calf $(<200 \mathrm{~kg}$ and/or $<175 \mathrm{~cm}$ ), subadult $(200-300 \mathrm{~kg}$ and/or $176-274 \mathrm{~cm})$ or

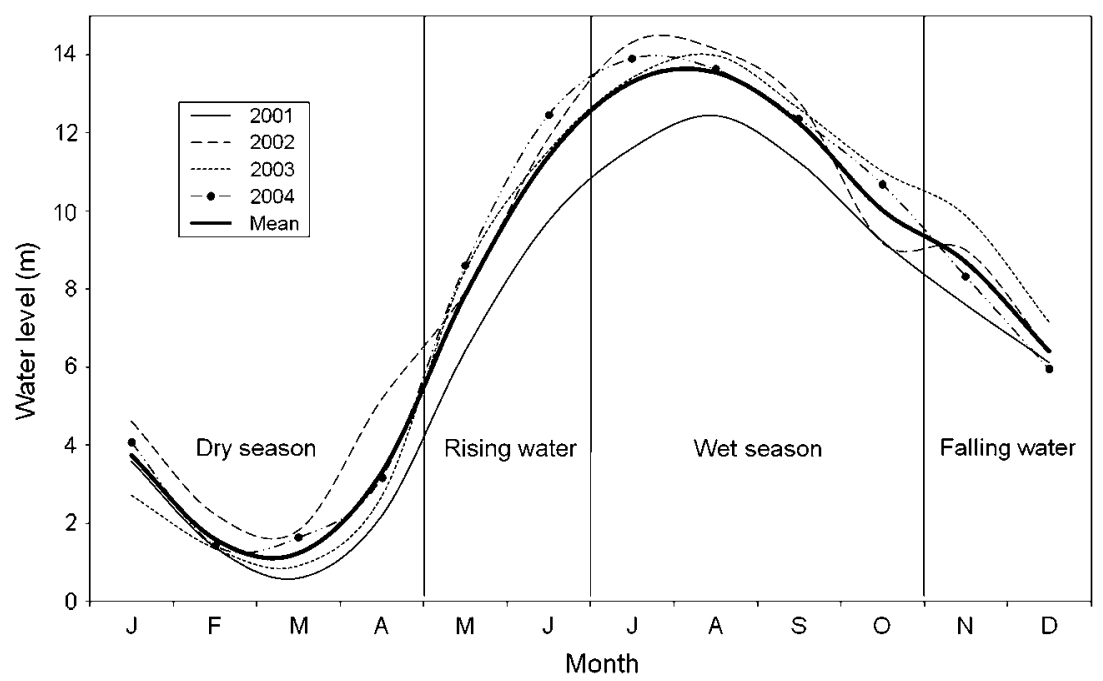

FIG. 1 Hydrological dynamics of the Orinoco River during 2001-2004 (data for 2005 were not available). Data are from Font Instituto de Hidrología, Metereología y Estudios Hidrográficos de Colombia. 

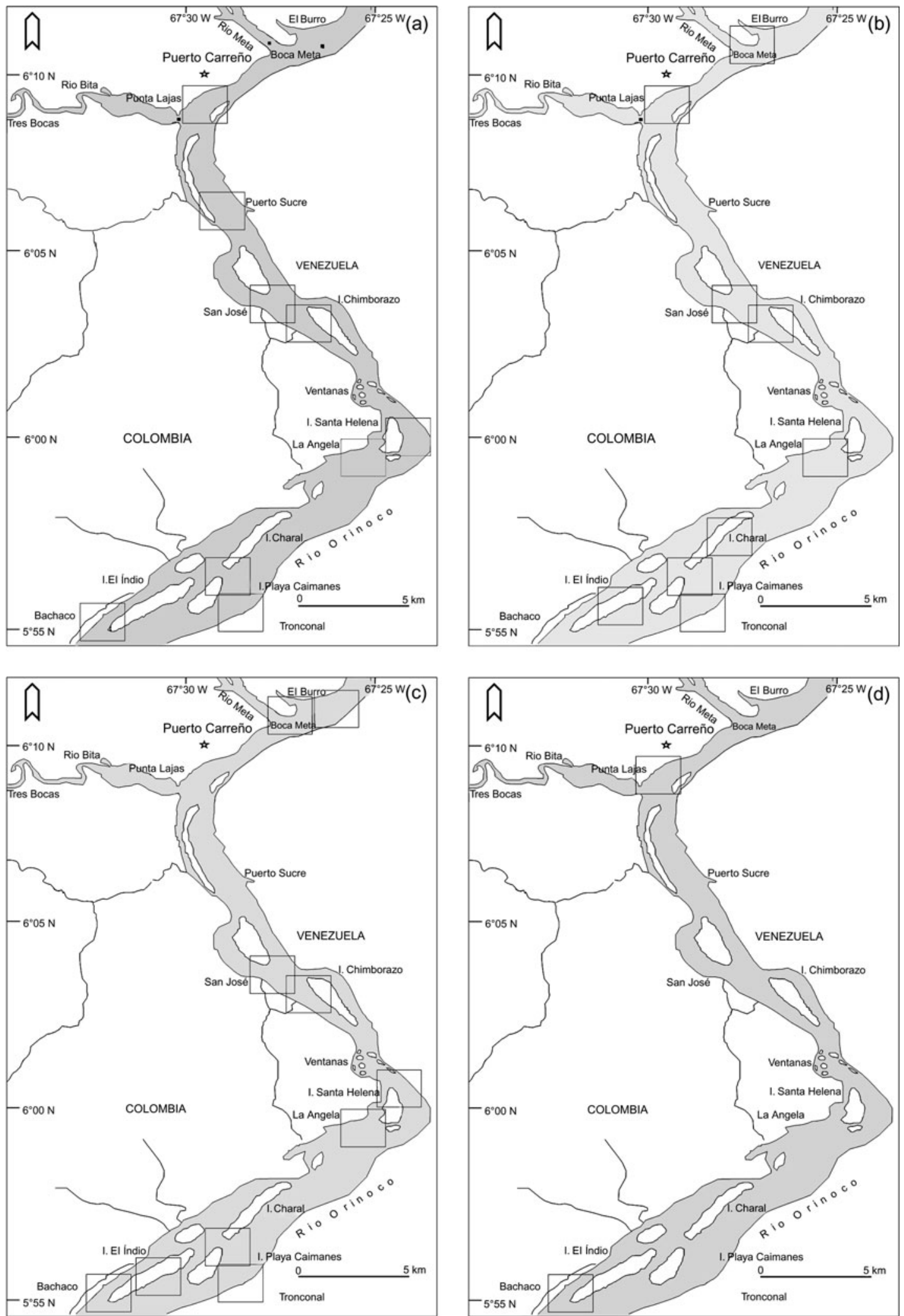

FIg. 2 The study area in the Orinoco River of Colombia. Rectangles represent areas where manatees were located (by sightings, feeding signs or interviewee reports of dead or injured manatees, see text for further details) during the (a) low water periods, (b) rising water periods, (c) high water periods and (d) falling water periods of 2001-2005. 
TABLE 1 Effort, in hours, of observations of manatees in eight areas of the Orinoco River (Fig. 2) during 2001-2005. For each site only years with observations are indicated.

\begin{tabular}{|c|c|c|c|c|c|}
\hline \multirow[b]{2}{*}{ Year } & \multicolumn{4}{|l|}{ Method used } & \multirow[b]{2}{*}{ Subtotal } \\
\hline & $\begin{array}{l}\text { Fixed point } \\
\text { on shore }\end{array}$ & $\begin{array}{l}\text { Boat } \\
\text { transect }\end{array}$ & $\begin{array}{l}\text { Fixed point } \\
\text { from boat }\end{array}$ & $\begin{array}{l}\text { Survey } \\
\text { on foot }\end{array}$ & \\
\hline \multicolumn{6}{|c|}{ Punta Lajas } \\
\hline 2003 & 28 & 28 & & & 56 \\
\hline \multicolumn{6}{|c|}{ Puerto Sucre } \\
\hline 2003 & 28 & 30 & & & 58 \\
\hline 2005 & 3.5 & 1.5 & 6 & & 11 \\
\hline \multicolumn{6}{|c|}{ San José } \\
\hline 2001 & 287 & 28 & & 9 & 324 \\
\hline 2002 & 127 & 32 & & & 159 \\
\hline 2003 & 28 & 26 & 23 & & 77 \\
\hline 2004 & 19 & 1 & & & 20 \\
\hline 2005 & 7 & 2 & 17 & & 26 \\
\hline \multicolumn{6}{|c|}{ Ventanas } \\
\hline 2001 & 4 & & & & 4 \\
\hline 2003 & 6 & & & & 6 \\
\hline \multicolumn{6}{|c|}{ I. Santa Helena } \\
\hline 2003 & 24 & 24 & 24 & & 72 \\
\hline 2004 & 3 & & & & 3 \\
\hline \multicolumn{6}{|c|}{ La Angela } \\
\hline 2003 & & & 26 & & 26 \\
\hline 2004 & & 1 & & & 1 \\
\hline \multicolumn{6}{|c|}{ I. Charal } \\
\hline 2003 & & & 26 & & 26 \\
\hline \multicolumn{6}{|c|}{ Tronconal } \\
\hline 2001 & 14 & & & 2 & 16 \\
\hline 2002 & & & 42 & & 42 \\
\hline 2003 & 13 & 13 & & & 26 \\
\hline 2004 & 16 & 4 & & & 20 \\
\hline 2005 & 10 & 2 & 18 & & 30 \\
\hline Total & 618 & 192 & 182 & 11 & 1,003 \\
\hline
\end{tabular}

adult $(>300 \mathrm{~kg}$ and/or $>275 \mathrm{~cm})$. These classes are based on size-specific reproduction data estimated for the species (Marmontel, 1993). Data were rejected if information about the period or location were not provided, if the information was not from the Orinoco River, or if the report pre-dated 1980 (to reduce the risk of errors arising from the passage of time). Reports from different sources were compared to avoid repetitions. If two or more reports had data that coincided, they were considered as the same event. When necessary, interviewees were contacted again to verify information.

\section{Results}

In 1,002.5 hours of observation we sighted 870 manatees, an average of 0.87 per hour (Table 2) at Punta Lajas, Puerto Sucre, San José, Ventanas, Isla Santa Helena and Tronconal (Fig. 2). The maximum number of individuals observed simultaneously was 17 , in the rising water period of 2002 at Tronconal. Even though observations were made through-
TABLE 2 Total observation effort, number of sightings per year and total, number of sightings per hour and maximum number of simultaneous sightings (see text for details) of manatees in the study area (Fig. 2) between 2001 and 2005, during periods of low, rising, high and falling water.

\begin{tabular}{lccll}
\hline & $\begin{array}{l}\text { Low } \\
\text { water }\end{array}$ & $\begin{array}{l}\text { Rising } \\
\text { water }\end{array}$ & $\begin{array}{l}\text { High } \\
\text { water }\end{array}$ & $\begin{array}{l}\text { Falling } \\
\text { water }\end{array}$ \\
\hline $\begin{array}{l}\text { Total effort (h) } \\
\text { Number of sightings }\end{array}$ & 651.5 & 203 & 126 & 22 \\
2001 & 331 & 35 & & \\
2002 & 183 & 99 & & \\
2003 & 56 & 1 & 0 & \\
2004 & & & 0 & 0 \\
2005 & 165 & & & \\
$\begin{array}{l}\text { Total } \\
\text { No. of sightings }\end{array}$ & 735 & 135 & 0 & 0 \\
$\quad$ per hour & 1.13 & 0.67 & 0.00 & 0.00 \\
$\begin{array}{l}\text { Max. no. of } \\
\text { simultaneous sightings }\end{array}$ & 8 & 17 & 0 & 0 \\
\hline
\end{tabular}

out the various hydroclimatic periods, manatees were only observed during the low and rising water periods (JanuaryJuly) in water depths of $2.0-21.2 \mathrm{~m}$. After 776 hours searching for feeding signs, 69 manatee feeding areas were located, at San José and La Angela, and near the islands of Chimborazo, El Índio, Charal and Playa Caimanes (Table 3). All of the feeding areas were located during the rising and high water periods.

From the interviews a total of 144 dead and wounded manatees were reported. Following validation the number of cases reduced to 92 during 1980-2004 (Table 4). The most common causes of mortality or wounding were incidental drowning in fishing nets (43.3\%) and hunting with harpoons (38.9\%). Cases of beach stranding (5.6\%), floating or stranded carcasses $(7.8 \%)$, bullet wounds $(2.2 \%)$ and collision with boats with engines $(2.2 \%)$ were also reported. Of the 90 cases, 37 dead or injured manatees were in the study area.

In total, from sightings, feeding areas and reports of mortality, we located manatees in 14 locations in the study area (Fig. 2, Table 5). During the low water period manatees

TABLE 3 Effort (in hours) spent searching for manatee feeding areas in 2001-2004 in the study area (Fig. 2), number of feeding areas located, and minimum and maximum water depth at feeding locations.

\begin{tabular}{llcll}
\hline Year & $\begin{array}{l}\text { Effort } \\
(\mathrm{h})\end{array}$ & $\begin{array}{l}\text { No. of } \\
\text { feeding areas }\end{array}$ & $\begin{array}{l}\text { Min. water } \\
\text { depth }(\mathrm{m})\end{array}$ & $\begin{array}{l}\text { Max. water } \\
\text { depth }(\mathrm{m})\end{array}$ \\
\hline 2001 & 128 & 6 & 2.5 & 5 \\
2002 & 128 & 24 & 1 & 4 \\
2003 & 256 & 39 & 1 & 6 \\
2004 & 264 & 0 & & \\
Total & 776 & 69 & 1.5 (mean) & 5.0 (mean) \\
\hline
\end{tabular}


TABLE 4 Number of cases of dead or injured manatees in the Orinoco River during 1980-2004 based on information obtained in interviews with local people.

\begin{tabular}{|c|c|c|c|c|c|c|c|}
\hline \multirow[b]{2}{*}{ Size class ${ }^{*}$} & \multicolumn{6}{|c|}{ Causes of mortality or wounding } & \multirow[b]{2}{*}{ Total } \\
\hline & $\begin{array}{l}\text { Drowning in } \\
\text { fishing nets }\end{array}$ & $\begin{array}{l}\text { Harpoon } \\
\text { hunting }\end{array}$ & Stranding & $\begin{array}{l}\text { Collision } \\
\text { with boat }\end{array}$ & $\begin{array}{l}\text { Floating/stranded } \\
\text { carcasses }\end{array}$ & $\begin{array}{l}\text { Bullet } \\
\text { wounds }\end{array}$ & \\
\hline Calves & 13 & 6 & & & & & 19 \\
\hline Subadults & 8 & 4 & 1 & & 1 & 2 & 16 \\
\hline Adults & 10 & 17 & 3 & 1 & 3 & & 34 \\
\hline Unknown & 8 & 8 & 3 & 1 & 3 & & 23 \\
\hline Total & 39 & 35 & 7 & 2 & 7 & 2 & 92 \\
\hline
\end{tabular}

${ }^{\star}$ Marmontel (1993), see text for further details

were observed in a continuous area from Punta Lajas to the tip of Isla Santa Helena. The places where the individuals were observed during the dry period are known locally as buceaderos, zones that still have a high water level during this time. When the river started rising sightings were made and feeding areas located from San José to Isla El Índio. La Angela, Isla Charal and Tronconal were important feeding sites during this period. In the high water period evidence of feeding was found in La Angela and around the islands of Chimborazo, Playa Caimanes and El Índio. In the decreasing water period we did not locate any feeding areas or manatees but two cases of dead animals were reported at Punta Lajas and Bachaco.

\section{Discussion}

Hunting and incidental drowning of the Antillean manatee in fishing nets in the Orinoco appears to be seasonal. Both occupation of habitat by manatees and the intensity and type of artisanal fishing used in the Orinoco depend on the availability of aquatic macrophytes and fish, respectively.

TABLE 5 Occurrence of manatees at 14 locations in the study area (Fig. 2) during 2001-2005.

\begin{tabular}{lllll}
\hline Site & $\begin{array}{l}\text { Low } \\
\text { water }\end{array}$ & $\begin{array}{l}\text { Rising } \\
\text { water }\end{array}$ & $\begin{array}{l}\text { High } \\
\text { water }\end{array}$ & $\begin{array}{l}\text { Falling } \\
\text { water }^{*}\end{array}$ \\
\hline $\begin{array}{l}\text { El Burro } \\
\text { Boca Meta }\end{array}$ & & M & M & \\
$\begin{array}{l}\text { Punta Lajas } \\
\text { Tres Bocas }\end{array}$ & M,S & M & & \\
$\begin{array}{l}\text { Puerto Sucre } \\
\text { San José }\end{array}$ & M,S & & & M \\
$\begin{array}{l}\text { I. Chimborazo } \\
\text { I. Santa Helena }\end{array}$ & S,S & F,M,S & M & \\
$\begin{array}{l}\text { La Angela } \\
\text { I. Charal }\end{array}$ & $\mathrm{M}$ & F & F & \\
$\begin{array}{l}\text { I. Playa Caimanes } \\
\text { I. El Indio }\end{array}$ & $\mathrm{M}$ & F,M & F & \\
Tronconal & & F & F,M & \\
Bachaco & S & M,S & M & \\
\hline
\end{tabular}

${ }^{\star} \mathrm{F}$, feeding areas; $\mathrm{M}$, reports of dead or injured individuals; $\mathrm{S}$, sightings
The availability of these resources is strongly influenced by the seasonal variations in water level. Fig. 3 describes the peaks of manatee mortality related to fishing activity, based on the explanations of local fishermen.

In the dry period (January-April) there is little vegetation available for the manatee (Correa-Viana et al., 1990) and the water level of the tributaries recedes so much that the manatees are isolated in buceaderos, where they probably feed on dead material from the bottom or algae on rocks. During December-March the river is at its most transparent (Castelblanco-Martínez, 2004); most of the fishing for palometa (Mylossoma spp.) is by hook and the use of nets is infrequent. This would explain the relatively low occurrence of incidental captures in fishing nets during the dry period. Although Mondolfi (1974) reports the hunting of manatees in the dry period, most of the hunters interviewed said that it is not a good period to harpoon the species.

As the river starts to rise (May-June) water covers the beaches and triggers the growth of aquatic macrophytes, which spread rapidly. This is when the manatees start moving to look for food and refuge in the margins of the river. Water transparency decreases drastically, making it impossible to fish with hooks, and nets then become the main means of fishing. During this period nets are put in areas that could be important corridors for manatees, increasing the risk of them being caught.

In the high water period (July-October) fishing activity is minimal because yield in terms of density and size of fish drops markedly (Barbarino Duque \& Winemiller, 2003). In addition, the manatees spread out in the esteros (a vernacular name for the flooded plain of the Orinoco River and tributaries), occupying fields of floating grass or flooded forests, where the use of nets is infrequent and thus incidental captures diminish. However, it is the best period for harpoon hunting, with the largest number of manatees harpooned during this period. O'Shea et al. (1988) also documented a high frequency of manatee hunting in the high water period in the Orinoco. The explanation given by the interviewees is that in the high water period hunting is easier because of the presence of feeding areas; 


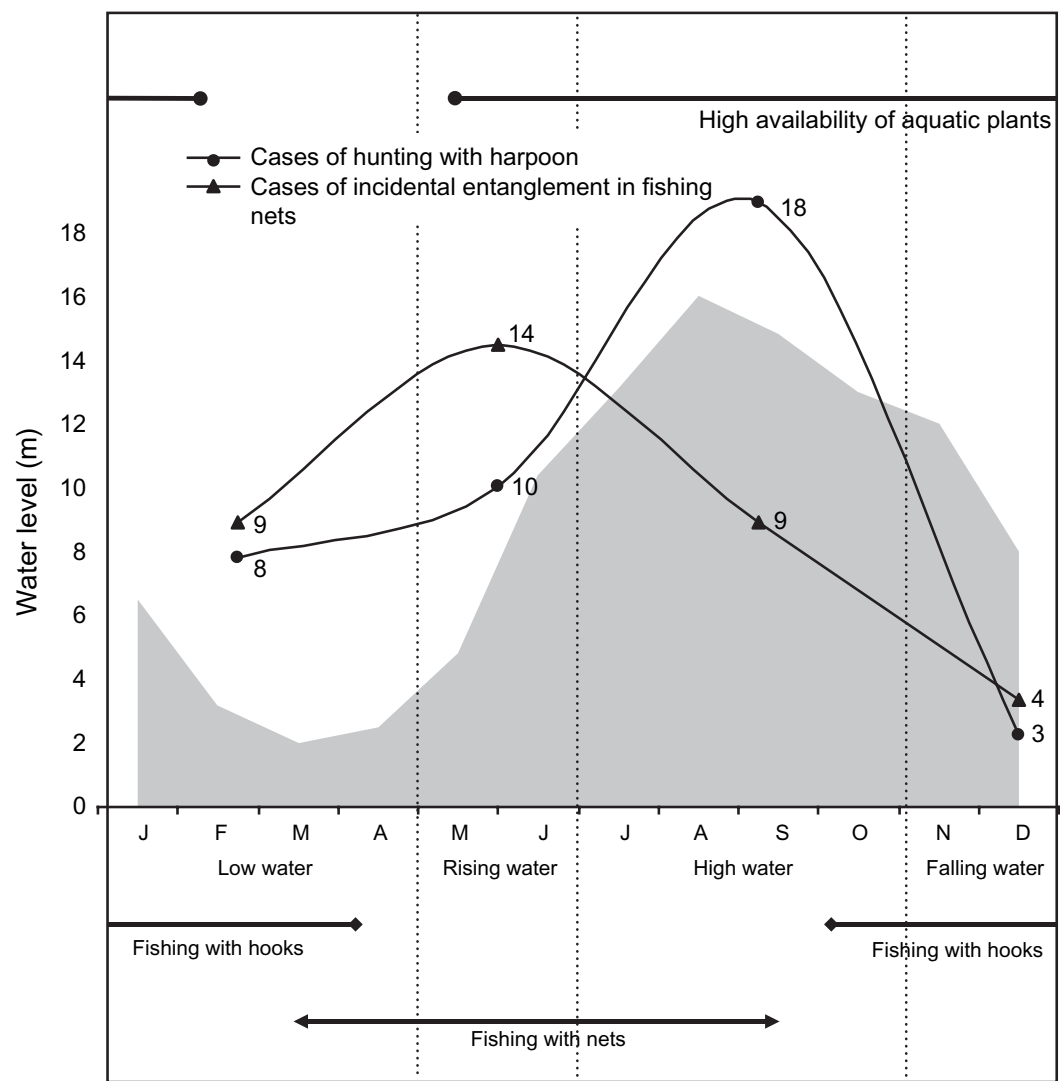

FIG. 3 The dynamics of Antillean manatee mortality in the Orinoco River in relation to the seasonality of fishing activities. The cases of manatees hunted or entangled in fishing nets occurred during 1980-2004 (see text for details). The grey area represents the seasonal water level fluctuation. During the low water period (January-April) manatees are isolated in buceaderos (the deepest areas of the river). When the water rises (May-June) manatees migrate in search of food. The peak of the net-fishing season is in the rising water period, which is thus the time of highest entanglement risk for manatees. During the high water period (July-October) manatees occupy the floodplains (esteros). In this season fishing activity is minimal because fish density falls and captures in fishing nets decrease. However, hunting for manatees with harpoons increases. The falling water period starts in November, and the manatees return to the areas of deep water.

the signs of feeding on the vegetation allow the manatees to be tracked. In addition it is difficult for a manatee to escape if harpooned in the estero because the harpoon usually entangles in the vegetation.

In November the water level begins to recede, the forest dries and the floating communities of macrophytes diminish. As a result, the manatees move from the esteros to the centre of the river, looking for sources of food such as plants on rocks.

The reproductive cycles of the fauna of river systems, including aquatic mammals, are synchronized to the environmental changes caused by the flood pulse (Robinson et al., 2002). During the dry period of 2001 we observed a group of adult manatees in the area of San José. At least five adults were seen to push and bump each other for a 2-hour period, probably carrying out a mating ritual (Hartman, 1979). Local fishermen claimed that mating behaviour of the manatee generally takes place during the dry season. The lower density of manatees during the high water period could reduce the possibility of encounters but in the dry period individuals are confined in relatively limited areas. The differential use of habitats seasonally could thereby determine the seasonality of reproduction (Marmontel et al., 1992). Further studies are needed to determine any seasonality in the reproduction of manatees in the Orinoco and the factors regulating the reproductive cycle of this population.

The Florida manatee carries out seasonal migrations, covering hundreds of kilometres (Deutsch et al., 2003) in response to seasonal variations in water temperature and the necessity to drink fresh water (Hartman, 1979). However, it is probable that the manatees of the Orinoco do not move far (Correa-Viana et al., 1990), living permanently in fresh water $>1,100 \mathrm{~km}$ from the sea. The habitat of the T. m. manatus population that lives in the Orinoco River can be compared to that of the Amazonian manatee T. inunguis (Junk et al., 1989; Colonello, 1990). Both live in dynamic river systems that have high seasonal variations in water levels, and consequently in their depth, current, transparency, margin characteristics, intensity and type of fishing and movement of boats. Such changes determine the availability of habitat for the manatee, and oblige 
individuals to move locally in search of suitable conditions. Although further information is needed to confirm the hypothesis, evidence suggests a converging adaptation in the behaviour and physiology of the Orinoco and Amazon manatees in response to similar environmental characteristics. It is possible that adaptation to seasonally minimal resources (Colares \& Colares, 2002) could be more efficient energetically than long distance migrations (Reid et al., 1991; Deutsch et al., 1998).

Our results indicate that habitat use by the Antillean manatee in the Orinoco depends on the availability of vegetation in the high water period and on the presence of deep-water areas in the dry period. These results also show that the main causes of mortality of the manatee are anthropogenic and influenced by hydrological fluctuations. Fishing activities and movement of boats need to be studied to determine the influence of these factors on reproduction and migration. During the transition periods areas such as Ventanas or Tronconal are important corridors and therefore require appropriate management.

Our results have been taken into account in several manatee conservation initiatives promoted by NGOs and local governments. We further recommend continued educational campaigns with the local communities along the Orinoco River, to discuss the main conservation problems of the manatee and clarify and divulge the existing legislation. The results and conclusions of this study formed part of the basis for the establishment of a national plan for the management and conservation of manatees in Colombia (Caicedo-Herrera et al., 2005), and the management plan for the threatened species of the Reserva de Biósfera El Tuparro (Trujillo et al., 2008).

\section{Acknowledgements}

This study was possible thanks to the logistical support offered by Fundación Omacha and the help of its directors, researchers and drivers. The project received financial help from Sirenian International, Columbus Zoo and Aquarium, Iniciativa para Especies Amenazadas (Convenio Fondo para la Acción Ambiental/Fundación Omacha/Conservación Internacional-Colombia). A study grant was provided by the convention Programa de Estudante-Convênio de Pós-Graduação of Ministério de Ciência e Tecnologia of Brazil. We also recognize the help of Instituto de Ciencias Naturales (Universidad Nacional de Colombia), Universidad Jorge Tadeo Lozano, and Instituto Nacional de Pesquisas da Amazônia (Brazil). Sarita Kendall, Dalila Caicedo, Benjamin Morales-Vela, Vera da Silva and Daryl P. Domning provided insightful comments. Dr Robert Bonde, Mario Rivera and two anonymous referees helped to improve the article. We especially thank the spontaneous collaboration of the fishing communities in the study area. We thank Kesä K. Lehti for the translation.

\section{References}

Barbarino Duque, A. \& Winemiller, K.O. (2003) Dietary segregation among large catfishes of the Apure and Arauca Rivers, Venezuela. Journal of Fish Biology, 63, 410-427.

Caicedo-Herrera, D., Trujillo, F., Rodríguez, C.L. \& Rivera, M. (eds) (2005) Programa Nacional de Manejo y Conservación de Manatíes en Colombia. Ministerio del Medio Ambiente, Vivienda y Desarrollo Territorial, Fundación Omacha, Bogotá, Colombia.

Castelblanco-Martínez, D.N. (2004) Peixe boi Trichechus manatus manatus na Orinoquia Colombiana: Status de conservação e uso de habitat na época seca. MSc Biología de Agua Doce e Pesca Interior, Instituto Nacional de Pesquisas da Amazônia/ INPA, Manaus, Brazil.

Colares, I.G. \& Colares, E.P. (2002) Food plants eaten by Amazonian manatees (Trichechus inunguis, Mammalia: Sirenia). Brazilian Archives of Biology and Technology, 45, 67-72.

Colonello, G. (1990) Elementos fisiográficos y ecológicos de la Cuenca del Río Orinoco y sus rebalses. Interciencia, 15, 476-485.

Correa-Viana, M., O'Shea, T.J., Ludlow, L.E. \& Robinson, J.G. (1990) Distribución y abundancia del manatí, Trichechus manatus, en Venezuela. Biollania, 7, 101-123.

Deutsch, C.J., Bonde, R.K. \& Reid, J.P. (1998) Radio-tracking manatees from land and space: tag design, implementation, and lessons learned from long-term study. Marine Technology Society Journal, 32, 18-29.

Deutsch, C.J., Reid, J.P., Bonde, R.K., Easton, D.E., Kochman, H.I. \& O'SHEA, T.J. (2003) Seasonal movements, migratory behavior and site fidelity of West Indian manatees along the Atlantic Coast of the United States. Wildlife Monographs, 151, $1-77$.

Flamm, R.O., Ward, L.I. \& Weigle, B.L. (2001) Applying a variable-shape spatial filter to map relative abundance of manatees (Trichechus manatus latirostris). Landscape Ecology, 16, 279-288.

Hamilton, S.K. \& Lewis, W.M. (1990) Physical characteristics of the fringing floodplain of the Orinoco River, Venezuela. Interciencia, 15, 491-500.

HARTMAN, D.S. (1979) Ecology and behavior of the manatee (Trichechus manatus) in Florida. Cornell University, New York, USA.

IUCN (2008) 2008 IUCN Red List of Threatened Species. IUCN, Gland, Switzerland. Http://www.redlist.org [accessed 7 July 2008].

Junk, W.J., Bayley, P.B. \& Sparks, R.E. (1989) The flood pulse concept in river-floodplain systems. In Proceedings of International Large River Symposium (ed. D.P. Dodge), pp. 110-127. Canadian Special Publication in Fisheries and Aquatic Sciences, Ottawa, Canada.

Lefebvre, L.W., Marmontel, M., Reid, J.P., Rathbun, G.B. \& Domning, D.P. (2001) Distribution, status, and biogeography of the West Indian manatee. In Biogeography of the West Indies: Patterns and Perspectives (eds C.A. Woods \& F.E. Sergile), pp. 425-474. CRC Press, Boca Raton, USA.

Marmontel, M. (1993) Age determination and population biology of the Florida manatee. PhD thesis, University of Florida, Gainesville, USA.

Marmontel, M., Odell, D.K. \& Reynolds, J.E. (1992) Reproductive biology of South American manatees. In Reproductive Biology of South American Vertebrates (ed. W.C. Hemlett), pp. 295-312. Springer-Verlag, New York, USA.

MARSH, H. (2000) Evaluating management initiatives aimed at reducing the mortality of dugongs in gill and mesh nets in the Great Barrier Reef World Heritage Area. Marine Mammal Science, 16, 684-694. 
Mondolfi, E. (1974) Taxonomy, distribution, and status of the manatee in Venezuela. Memorias de la Sociedad de Ciencias Naturales "La Salle", 34, 5-23.

O’Shea, T.J. \& Ackerman, B.B. (1995) Population biology of the Florida manatee: an overview. In Population Biology of the Florida Manatee. National Biological Service Information and Technology Report 1 (eds T.J. O’Shea, B.B. Ackerman \& F. Percival), pp. 280-288. Department of Interior, Washington, DC, USA.

O'Shea, T.J., Correa-Viana, M., Ludlow, M.E. \& Robinson, J.G. (1988) Distribution, status, and traditional significance of the West Indian manatee Trichechus manatus in Venezuela. Biological Conservation, 46, 281-301.

Reid, J.P., Rathbun, G.B. \& Wilcox, J.R. (1991) Distribution patterns of individually identifiable West-Indian manatees (Trichechus manatus) in Florida. Marine Mammal Science, 7, 180-190.

Robinson, C.T., Tockner, K. \& Ward, J.V. (2002) The fauna of dynamic riverine landscapes. Freshwater Biology, 47, 661-677.

Trujillo, F., Portocarrero, M. \& Gómez, C. (eds) (2008) Plan de Manejo y Conservación de Especies Amenazadas en la Reserva de Biósfera El Tuparro: Delfines de río, Manatíes, Nutrias, Jaguares y Tortugas del género Podocnemis. Proyecto Pijiwi
Orinoko (Fundación Omacha-Fundación Horizonte Verde), Forest Conservation Agreement, Bogotá, Colombia.

Vasquez, E. \& Wilbert, W. (1992) The Orinoco: physical, biological and cultural diversity of a major tropical alluvial river. In The Rivers Handbook, Vol. 1 (eds P. Calow \& G.E. Petts), pp. 448-471. Blackwell Scientific Publications, London, UK.

\section{Biographical sketches}

Nataly Castelblanco-Martínez has developed research and educational projects on aquatic fauna in South American rivers, studying the distribution, ecology and conservation of manatees, dolphins, otters and turtles. She is now studying the ecology of Caribbean manatees in Mexico. Isabel Gómez and Lucia Bermudez participated in a manatee conservation project in the Orinoco River for their graduate studies. FERNANDo C.W. Rosas has been studying the ecology and conservation of aquatic mammals in the Brazilian Amazon for over 25 years. Fernando Trujillo is founder and scientific director of the Fundación Omacha, an NGO created to protect fauna and aquatic ecosystems in Colombia. ENRIQUE ZERDA - ORD OÑEZ teaches animal behaviour at the Universidad Nacional de Colombia. 